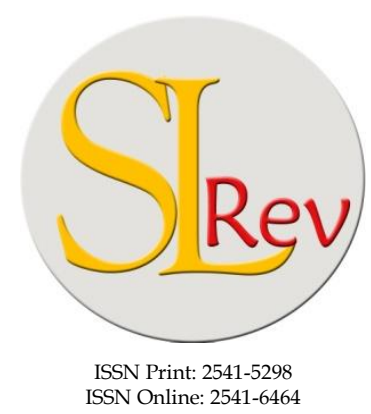

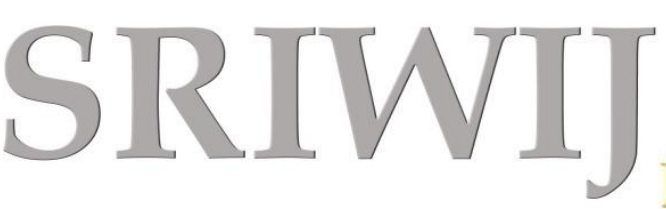

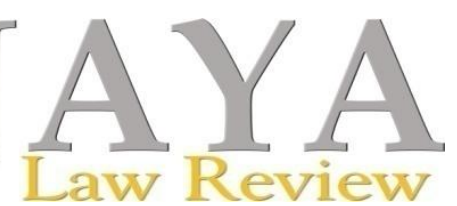

Editorial Office: Faculty of Law, Sriwijaya UniversityJalan Srijaya Negara, Palembang, South Sumatra 30139, Indonesia. Phone: +62711-580063Fax: +62711-581179

E-mail: sriwijayalawreview@unsri.ac.id|sriwijayalawreview@gmail.com Website: http://journal.fh.unsri.ac.id/index.php/sriwijayalawreview

\title{
Inability of Protecting Diplomats: Problems of Afghanistan and Conflict Countries
}

\author{
Ananda Kurniawan Sukarmaji ${ }^{*}$ and Arie Afriansyah ${ }^{* *}$
}

\begin{abstract}
This article discusses the protection of diplomats and state responsibility of physical suffering of diplomats in conflict countries, especially in Afghanistan using juridical normative methodology. This concern has to be discussed because there are a lot of attacks and physical harms suffered by the diplomats, especially in armed-conflict countries. This article analyzes the practices of protection of diplomats in some conflict countries and explain the conventions that include protection of diplomats as a part of the conventions. Thus, conflict countries are more tendentious than non-conflict countries in terms of numbers of attacks and physical harms suffered by diplomats. Therefore, this article analyzes the conflict country and categorizes the terms and conditions in the conflict countries. After looking into the pattern of protection of diplomats in some countries, this article analyzes the response shown by the receiving and sending state. There is also a discussion of the attacked diplomat cases in Afghanistan and the responses issued by the related parties. Then, protection of the diplomats and state responsibility are analyzed based on the related doctrine and conventions. Changes in protection of diplomats in Afghanistan should be done and Afghanistan should be more concerned about this matter and based on the diplomatic convention, sending state could file a dispute settlement to an arbitrary organ and International Court of Justice to claim state responsibility. Based on the conventions and doctrine related, Afghanistan could be charged as the full responsible party.
\end{abstract}

Keywords: Protection of Diplomats; State Responsibility; Conflict Countries; Afghanistan.

\section{ARTICLE HISTORY:}

\section{DOI: 10.28946/slrev.Vol2.Iss1.108.pp18-44}

Received: Apr 11, 2017;

Reviewed: May 10, 2017;

Accepted: July 10, 2017;

Published: Jan 31, 2018;

Citation: V.2.1 SLRev. 2018.

* Faculty of Law, University Indonesia,
Jakarta
Faculty of Law, University Indonesia,
Jakarta
E-mail: arie.afriansyah@ui.ac.id

\section{INTRODUCTION}

The concept of immunity and privilege has been widely recognised and applied by the international community since Roman Empire, Greek Empire, and Babylonia Empire. It was even applied in ancient Indian, Egyptian, Chinese and Israel too. Envoys, in those times, already had diplomatic immunity and 
privilege within them. ${ }^{1}$ In this case, for example, Roman Empire applied immunity and privilege into envoys, hence wherever the envoy went, the inviolability laid on them. ${ }^{2}$

This concept did not improve until Renaissance era when the development of modern diplomacy was established. It is proven by the establishment of the first permanent mission found in Europe and it was a new concept in diplomacy. ${ }^{3}$ The Italians were the first nation aware of the beneficial effects of this new concept. Venezia, the neighboring country of Italy, sent the first ever ambassador to Italy based on their mutual interests. ${ }^{4}$ Hence, more diplomatic permanent missions appeared in more countries, such as Italian ambassador in London, Paris and other major countries. ${ }^{5}$

The development of immunity and privilege concept developed and finally a new stepping stone was also made. In this case, there was an understanding that immunity also meant that an ambassador was not liable to any form of court and administrative jurisdiction of receiving state. ${ }^{6}$ The judges in the classic case

\footnotetext{
${ }^{1}$ David J. Bederman, International Law in Antiquity, Cambridge University Press, 2001, p176.

${ }^{2}$ J. Alan, Hostages and Hostage Takers in the Roman Empire, Cambridge University Press, 2006, p64

${ }^{3}$ L.S. Farhangi, "Insuring against Abuse of Diplomatic Immunity", Stanford Law Review Vol. 38, No. 6, 1985-1986, p1518.

${ }^{4}$ Eileen Young, "The Development of The Law of Diplomatic Relations", British Yearbook of International Law Vol. 40, No.1, 1964, pp142.

${ }^{5}$ Harold Nicolson, Diplomacy, Institute for the Study of Diplomacy, 1988, p30.

${ }^{6}$ Rene Vark, "Personal Inviolability and Diplomatic Immunity in Respect of Serious Crime", Juridica International Vol. 8, 2003, p113.
}

of Empson vs Smith emphasized "It is elementary law that diplomatic immunity is not immunity from legal liability, but immunity from suit". 7 We can certainly see from this statement that an ambassador was not under the jurisdiction of receiving state, but the ambassador had to respect the law of the receiving state. ${ }^{8}$

The 1815 Vienna Congress resulted in the established rules of diplomatic law. Aix-La-Chapelle Protocol also completed the text. This development indicated the urgency of diplomatic law and diplomacy as a whole to the international community. The progress of diplomatic law kept moving forward and the establishment of Havana Convention 1928 on Diplomatic Immunity was finally made. ${ }^{9}$ However, this convention was only a regional convention. League of Nations did not establish a global rule related to the diplomatic law. Meanwhile, Havana Convention became a pioneer and was the first formal codification of diplomatic law. ${ }^{10}$

After the World War 2, International Law Commission established by the United Nations made a list of some topics to be discussed. Diplomatic Immunity and privilege was also one of the topics. But it was not the main concern of the committee, thus there was not a maximized result related to the existence of codification of diplomatic law globally.

\footnotetext{
${ }^{7}$ Note 6.

${ }^{8}$ Note 6

${ }^{9}$ Montell Ogdon, "The growth of the Purpose In The Law of Diplomatic Immunnity", The American Journal of International Law Vol. 31, No.3, 1937, p449.

${ }^{10}$ Arthur Nussabaum, A Conchise History of the Law of Nations, s.n., 1969, p7.
} 
It was not until 1959 a diplomatic law conference was ordered to be held based on Resolution 1450 (XIV) of General Assembly United Nations. This conference was named "The United Nations Conference on Diplomatic Intercourse and Immunities" and held from March 2 to April 14, 1961. The conference produced some law products, such as Vienna Convention on Diplomatic Relations, Optional Protocol Concerning Acquisition of Nationality, and Optional Protocol Concerning the Compulsory Settlement of Disputes. ${ }^{11}$ After the establishment of Vienna Convention on Diplomatic Relations of 1961, more diplomatic law conventions were also established, such as Convention on the Protection and Punishment of Crimes against Internationally Protected Persons, including Diplomatic Agents, Convention on Special Missions, Vienna Convention on Consular Relations and Vienna convention on the representatives of state in their relations with international organizations of a universal character. These conventions completed Vienna Convention on Diplomatic Relations to create a global norm of diplomatic law as we know it today. ${ }^{12}$

The inviolability of diplomatic staff is one of the key rules in Vienna Convention on the Diplomatic Relations and other diplomatic conventions. ${ }^{13}$ This also means that receiving state has responsi-

\footnotetext{
${ }^{11}$ Syahmin AK, Hukum Perjanjian Internasional: Menurut Konvensi Wina 1969, CV. Armico, $1985, \mathrm{p} 16$.

${ }^{12}$ Joseph S. Nye, "The Changing Nature of World Power", Political Science Quarterly, Vol. 105, No. 2, 1990, p190.

${ }^{13}$ Vienna Convention on Diplomatic Relations 1961, opened for signature 18 April 1961, (entered into force 24 April 1964).
}

bility to protect diplomatic staff in their country with "all appropriate steps". Thus, the failure to fulfil such responsibility is a violation of international law and the convention. However, there has been an increasing statistical numbers of attacks on diplomatic staff across the world. The Landmark case of attacks on diplomatic staff was Iran Hostage Crisis, where 52 United States diplomatic staff became hostages for 444 days in Iran. ${ }^{14}$ In addition, attacks on diplomatic staff got worsen in 1980 where 400 terrorist attacks targeted diplomatic and consular staff in more than 60 countries.

Diplomatic staff posted in conflict countries became more vulnerable to the attacks of the terrorist groups. Thus, one of the most renowned conflict countries is Afghanistan, where the civil war and international armed conflict still occur in this country. Statistically, Afghanistan had the highest number of attacks on diplomatic staff from 2001 to $2017 .^{15}$ This is the problem faced by Afghanistan as a sovereign country. The government could not fulfil the needs and protection of the diplomats and it might create a worse situation domestically and globally. The sending state could not trust the ability of Afghan's officials to do their obligations. Moreover, the armed conflict in Afghanistan is still go-

\footnotetext{
${ }^{14}$ Tyler Q. Houlton, "The Impact of the 1979 Hostage Crisis in Iran on the U.S. Presidential Election of 1980", Thesis of Master of Arts in Liberal Studies Georgetown University, Washingtown D.C., 2011, p2.

15،Five UAE Diplomats Killed in Afghanistan Attack", http://www.aljazeera.com/news/2017/01/uaeambassador-afghanistan-wounded-kandaharblast-170110172931399.html, retrieved on 31 Januari 2017.
} 
ing on and attacks on diplomats in the future seem inevitable. Hence, Afghanistan is an interesting country to be discussed further based on the geo-political and legal perspectives. This inablity of Afghanistan has shown its own problem in wider perspectives.

Gennady M. Danilenko points out a similar issue regarding the application of Humanitarian and diplomatic law on the same case. In his Article entitled "The Relevance of Humanitarian and Diplomatic Law to the Conflict in the Gulf", Danilenko showed that humanitarian and diplomatic legal principles were firm and became the customary international law. ${ }^{16}$ Moreover, he also explained the breach of humanitarian and diplomatic law in the gulf war. However, this article explained a different part of the issue of the applicability of certain humanitarian and diplomatic principles in the armed conflict. In addition, it focused on applicability of diplomatic law more than the humanitarian law such as protection of diplomats, inviolability and state responsibility.

Besides, there was a bachelor law thesis written by Esther M.F. Warouw, entitled Tanggung Jawab Negara Melindungi Diplomat dan Gedung Perwakilan Asing (Studi Kasus: Kematian Duta Besar dan Pengrusakan Gedung Perwakilan Amerika Serikat di Benghazi Libya) (Translated: State Responsibility Protecting Diplomats and Foreign Representative Building (Case Study: Death of Ambassador and Destruction of

\footnotetext{
${ }^{16}$ Gennady M. Danilenko, "The Relevance of Humanitarian and Diplomatic Law to the Conflict in the Gulf', Duke Journal of Comparative and International Law, Vol. 125, 1991, p133.
}

United States Representative Building in Benghazi Libya)", described the state responsibility related to the Benghazi crisis. Compared to this article, there was another article discussing a much deeper perspective focusing on the the applicability of protection of diplomats and state responsibility in the conflict countries, including Afghanistan.

Conflict countries have their own domestic problems related to the humanitarian and human rights issue. But, they are not the only two issues that the countries faced. Afghanistan had a diplomatic issue regarding attacks of the diplomats in the country. But there might be a finding related to this issue, especially the one in Afghanistan and conflict countries facing their diplomatic and humanitarian problems. It is argued that Afghanistan is fully responsible for the attacks of the diplomats in its territory and Afghan officials failed to protect the diplomats and the premises based on the study cases given.

There are several supporting arguments to support the findings to be solved. The first supporting argument is the obligation of protecting diplomats and its consequences if it fails to do such obligations. This argument would help demonstrate the legal basis of all countries to protect diplomats in their countries. Then, further explanation of the consequences of failure to fulfil such obligations is provided such as a state responsibility. Second, it refers to the instability of conflict countries. This argument will help illustrate the humanitarian and diplomatic problem faced by the conflict countries. In addition, this argument categorizes what kind of 
armed conflict exists in each given conflict country. The last supporting argument is the inability of protecting diplomats by Afghanistan and its consequences. This argument emphasizes the attacks on the diplomats in Afghanistan and its analysis is based on its obligation to protect the diplomats and its consequences when it fails to fulfil the obligations.

This article starts with the introduction and background of the issue. Then, it continues to the first supporting argument, which is protecting diplomats and its consequences if fail to do such obligation. After that, second supporting argument will be next, which is the instablity of conflict countries. The fourth part is the last supporting argument which is the inability to protect diplomats by Afghanistan and its consequences. The last part is the concluding part of the article.

\section{ANALYSIS AND DISCUSSION Protecting Diplomats and Its Conse- quences if Failing to Do Such Obliga- tion}

\section{A. Protection of Diplomats}

One of the key points related to the attacks on the diplomats is how the receiving state protects the sending state's diplomats. Protection of diplomats, as previously described, is an integral norm of Vienna Convention on Diplomatic Relations and other diplomatic conventions such as Convention on the Protection and Punishment of Crimes against Internationally Protected Persons, including Diplomatic Agents, Convention on Special Missions, Vienna Convention on Consular Relations and Vienna convention on the representatives of a state in their relations with international organizations of a universal character. These conventions regulate the obligations of a receiving state to protect foreign diplomats. They also emphasize the inviolability of the diplomats too, thus they ensure foreign diplomats' safety, even in a hostile country. ${ }^{17}$

The failure to fulfil the obligations means a violation to the convention. Moreover, based on the case of United States vs Iran, the protection of diplomats becomes a customary international law, which means the failure to do so is not only violation to the convention, but also a violation to the international law. ${ }^{18}$ It just shows the importance and essence of protection of diplomats to the diplomatic and international law norms as a whole. The following are the diplomatic conventions regulating the protection of diplomats as part of their norms.

\section{Vienna Convention on Diplomatic Relations}

Vienna Convention on Diplomatic Relations of 1961 is considered as the basic and fundamental diplomatic treaty. ${ }^{19}$ This convention gives structural and comprehensive regulation on the diplomatic law, which also regulates establishment, regulation and terminology in international relations based on the agreement between sovereign countries. Moreover, it also regulates the functions of diplomatic mission, designation or

\footnotetext{
${ }^{17}$ Eileen Denza, Diplomatic Law: Commentary on The Vienna Convention on Diplomatic Relations, Oxford University Press, 1998, p3.

${ }^{18}$ International Court of Justice, Case concerning United States Diplomatic and Consular Staff in Tehran (United States v. Iran), 24 Mei 1980, p1.

${ }^{19}$ Note 16.
} 
posting regulation, persona non grata, and the diplomatic rights and privileges. ${ }^{20}$

In terms of protection of diplomats, there are some rules that regulate how protection of diplomats should be done. Article 22 regulates the inviolability of the premises and the obligation of protecting the premises for a receiving state.

"1) The premises of the mission shall be inviolable. The agents of the receiving State may not enter them, except with the consent of the head of the mission.

2) The receiving State is under a special duty to take all appropriate steps to protect the premises of the mission against any intrusion or damage and to prevent any disturbance of the peace of the mission or impairment of its dignity.

3) The premises of the mission, their furnishings and other property thereon and the means of transport of the mission shall be immune from search, requisition, attachment or execution." 21

This article emphasizes that premises are inviolable to any kind of juridiction, therefore any agents of the receiving state may not enter the premises unless with the consent of the head of mission. In the next paragraph, it is shown that the receiving state has responsibility to protect the premises to any kind of intrusion or damage and prevent any disturbance of the peace of the premises. $^{22}$

\footnotetext{
${ }^{20}$ Note $16, \mathrm{p} 2$.

${ }^{21}$ Vienna Convention on Diplomatic Relations 1961, opened for signature 18 April 1961, (entered into force 24 April 1964). Art. 22.

${ }^{22} \mathrm{Yu}$ Long Ling, "A Comparative Study of the Privileges and Immunity of United Nations Member Representatives and Officials with the Traditional Privileges and Immunities of Diplomatic Agents", Washington and Lee Law Review, Vol. 33, Iss. 1, 1976, p103.
}

Another article that regulates protection of diplomats in this convention is article 29. This article explains that the diplomatic agent is inviolable. Then, this convention also contains two meanings. First point is that a receiving state does not have any jurisdiction on the diplomatic agent, in terms of criminal, private and administrative jurisdiction. ${ }^{23}$ Second point is that a receiving state has responsibility to protect diplomats from any kind of physical harm, freedom, or dignity. $^{24}$

\section{Convention on Special Mission}

There is a different kind of mission other than permanent mission, which is special missions. This mission is where a sending state sends their agent to a foreign country temporarily. ${ }^{25}$ The purpose of this convention is to provide legal basis on a special matter which is not included in the permanent missions. ${ }^{26}$ Usually, this special matter is established based on the agreement of both countries and the specific mission is also included in the agreement. ${ }^{27}$

Related to protection of special mission's agent, it is regulated in the articles 29 and 25 regulating the protection of both the special mission's premises and

\footnotetext{
${ }^{23}$ M.L. Benedek, "The Diplomatic Relations Act: The United States Protects Its Own", Brooklyn Journal of International Law Vol. 5, 1979, p379

${ }^{24}$ Note 23, p2.

${ }^{24}$ Vienna Convention on Diplomatic Relations 1961, opened for signature 18 April 1961, (entered into force 24 April 1964). Art. 29.

${ }^{25}$ Michael Wood, "The Immunity of Official Visitors", Max Planck Yearbook of United Nations Law Vol. 16, 2012, p49.

${ }^{26}$ Note 25.

${ }^{27}$ Convention on Special Mission 1969, opened for signature on 8 Decembe 1960, (entered into force 21 June 1985). Art. 1, let. (a).
} 
the special mission's agent itself. The receiving state has the same obligation compared to Vienna convention on diplomatic relations to protect and prevent any kind of harm and attacks on the diplomatic and special mission's staff. ${ }^{28}$

\section{Vienna Convention on Consular Relations}

The establishment of consular institution is one of the products from the trade and shipping activities. This trade had developed since Greek empire's regime, where there were trade exchanges and relations between city and states across the empire and at other cities in the middle-east. ${ }^{29}$ This trade community then built factories, offices and administrative places in another country and was under the jurisdiction of their origin country. Moreover, these coummunities got their own authonomy and rights, as known as consular. $^{30}$

This consular system has kept developing and becoming part of relationship in international and diplomacy communities. A convention which regulates counsular relations is Vienna Convention on Consular Relations. Like the other two diplomatic conventions, it also regulates the protection of consulat staff and consular premises based on the Article 40 of the convention: "The receiving state shall treat consular officers with due respect and shall take all appropriate

\footnotetext{
${ }^{28}$ Note 27, Art. 25 Par. (2) and Art. 29.

${ }^{29}$ Coleman Phillipson, The International Law and Customs of Ancient Greece and Rome, Macmillan and Co., 1911, pp149.

${ }^{30}$ Boer Mauna, Hukum Internasional: Pengertian, Peranan, dan Fungsi dalam Era Dinamika Global, Penerbit Alumni, 2000, p465.
}

steps to prevent any attack on their persons, freedom or dignity". ${ }^{31}$

It is clear that not only diplomatic staff who is given protection by the receiving state, but also consular staff who must be protected from any attack on them personally, freedom or dignity by the receiving state.

\section{Convention on the Prevention and Punishment of Crimes against Internationally Protected Persons, including Diplomatic Agent 1973}

This convention fulfils the void in terms of specific rules in protection of diplomats. This convention was established after a series of attacks and harms suffered by the diplomats years before this convention was finally established. Kidnap, murder and other kinds of attacks suffered by the diplomats became increasingly more vulnerable than ever before. Hence, this convention was finally established to be a legal basis of a more specific action with the intention of the protecting diplomats. ${ }^{32}$

From the Articles 1 and 2 of the convention, it is obvious that this convention provides protection to diplomats, their official premises, private accomodation or means of transport and the receiving state provides obligations to take all appropriate steps to prevent attacks

\footnotetext{
${ }^{31}$ Vienna Convention on Consular Relations 1963, opened for signature 24 April 1963, (entered into force 19 March 1967). Art. 40.

${ }^{32}$ Christos L. Rozakis, "Terrorism and the Internationally Protected Persons in the Light of the ILC's Draft Articles", The International and Comparative Law Quarterly Vol. 23, Iss. 1, 1974 p33.
} 
on the persons, freedom or dignity of an internationally protected persons. ${ }^{33}$

\section{Vienna Convention on the Representation of States in Their Relations with International Organizations of a Universal Char- acter 1975}

The discussion on establishing this convention has involved three different subjects of international law, that is international organization, state parties and international organization's host state. ${ }^{34}$ Nonetheless, the regulation of this convention in terms of protection of diplomats seems similar.

Based on the Articles 23 and 28 of the convention, the international organisation's staff and premises are inviolable. The receiving state has obligations to protect the mission of the international organisation and takes all appropriate steps to ensure no one does harm to diplomatic staff or premises. ${ }^{35}$ This has not yet entered into force; however, the legal and philosophycal norm of this convention has laid into other diplomatic conventions and customary international law.

If the contracting state fails to protect diplomats as a form of fulfilling its obligation, then the violating state would

\footnotetext{
${ }^{33}$ Convention on the Prevention and Punishment of Crimes against Internationally Protected Persons, including Diplomatic Agents 1973, opened for signature 14 December 1973, (entered into force 20 February 1977). Art. 1 and 2.

${ }^{34}$ Sumaryo Suryokusumo, Hukum Diplomatik Teori dan Kasus, Alumni, 2005, p22.

${ }^{35}$ Vienna Convention on the Representation of States in Their Relations with International Organisations of a Universal Character 1975, opened for signature 13 March 1975, (not yet entered into force). Art. 23 and 28.
}

face its consequences. The consequence is the violating country has to be responsible for the failure of meeting such obligation. What form of responsibility that violating country has to fulfil will be explained in the next sub-chapter.

\section{B. Consequences: State Responsibility}

If we take a look at diplomatic conventions, such as Vienna Convention on Diplomatic Relations of 1961, Vienna Convention on Consular Relations of 1963, Convention on Special Missions of 1969, Convention on the Prevention and Punishment of Crimes against Internationally Protected Persons including Diplomatic Agents of 1973, and Vienna Convention on the Representation of States in Their Relations with International Organizations. There is no mechanism of state responsibility if one of the state parties fails to fulfil obligations to protect diplomats and premises or other rules stated in the conventions. ${ }^{36}$

However, Vienna Convention on Diplomatic Relations of 1961, Vienna Convention on Consular Relations of 1963, and Convention on Special Missions of 1969 have optional protocols regarding compulsory settlement of disputes. These protocols have the same rule in their Article 1 stating:

"Dispute arising out of the implementation of the Convention shall lie within the compulsory jurisdiction of the International Court of Justice and may accord-

\footnotetext{
${ }^{36}$ Esther M.F. Warouw, "Tanggung Jawab Negara Melindungi Diplomat dan Gedung Perwakilan Asing (Studi Kasus: Kematian Duta Besar dan Pengrusakan Gedung Perwakilan Amerika Serikat di Benghazi Libya)", Thesis Bachelor of Law Universitas Indonesia, Depok, 2013, p45
} 
ingly be brought before the Court by an application made by any party to the dispute being a Party to the present Protocol., 37

Article 2 of additional protocols also states:

"The Parties may agree, within a period of two months after one party has notified its opinion to other that a dispute exist, to resort not to the International Court of Justice but to an arbitral Tribunal. After the expiry of the said period, either party may bring the dispute before the Court by an application." 38

Moreover, Convention on the Prevention and Punishment of Crimes against Internationally Protected Persons including Diplomatic Agents of 1973 also includes this kind of regulation stated in Article 13 Paragraph (1) as follows:

"Any dispute between two or more State Parties concerning the interpretation or application of this Convention which is not settled by negotiation shall, at the request of one of them, be submitted to arbitration. If within six months from the date of the request for arbitration the parties are unable to agree on the organization of the arbitration, any one of those parties may refer the dispute to the International Court of Justice by request in conformity with the Statute of the Court." 39

\footnotetext{
${ }^{37}$ Optional Protocol concerning Settlement of Disputes Vienna Convention on Diplomatic Relations 1961, opened for signature 18 April 1961, (entered into force 24 April 1964). Art.1, Optional Protocol concerning Settlement of Disputes Vienna Convention on Consular Relations 1963, opened for signature 24 April 1963, (entered into force 19 March 1967). Art.1, and Optional Protocol concerning Settlement of Disputes Convention on Special Mission 1969, opened for signature on 8 Decembe 1960, (entered into force 21 June 1985). Art.1.

${ }^{38}$ Note 37 , Art. 2

${ }^{39}$ Convention on the Prevention and Punishment of Crimes against Internationally Protected Persons, including Diplomatic Agents 1973,
}

In summary, if there is any dispute between two contracting states regarding diplomatic issues, one of the countries could file dispute settlement to an arbitrary institution. After some specific time (depending on the legal basis of the dispute) and there is no any consent between the two countries, then the dispute could be filed to International Court of Justice. $^{40}$

In the rules above, there are not any conventions or protocols regulating what form of responsibility has to be conformed by the country who fails to do its responsibility, including protecting foreign diplomats and premises. However, these regulations are stated in ILC Draft Articles on State Responsibility for Internationally Wrongful Acts (2001). First of all, a state responsibility could be given to violating country that somehow does internationally wrongful act. Article 2 ILC Draft Articles on State Responsibility for Internationally Wrongful Acts (2001) states:

"There is an internationally wrongful act of a State when conduct consisting of an action or omission: (a) is attributable to the State under international law; and (b)constitutes a breach of an international obligation of the State." ${ }^{41}$

Failing to conform obligations to protect diplomats as stated in the diplomatic conventions and the customary international law, then these two criteria

\footnotetext{
opened for signature 14 December 1973, (entered into force 20 February 1977). Art. 13 Par. (1)

${ }^{40}$ Note $35, \mathrm{p} 47$.

${ }^{41}$ ILC Draft Articles on State Responsibility for Internationally Wrongful Acts(2001), adopted by International Law Commission on 12 December 2001. Art. 2.
} 
have been conformed by the country failing to do such obligations. ${ }^{42}$

In terms of what kind of retribution a violating country has to conform, there are three forms of retribution that can be charged to the violating country, namely restitution, compensation, and satisfaction. These retributions are regulated from Articles 34 to 37 of ILC Draft Articles on State Responsibility for Internationally Wrongful Acts (2001).

Restitution is a form of retribution that restores all kinds of harms and damages before the attacks or incidents occurred. Article 35 states:

"A State responsible for an internationally wrongful act is under an obligation to make restitution, that is, to re-establish the situation which existed before the wrongful act was committed, provided and to the extent that restitution: (a) is not materially impossible; (b) does not involve a burden out of all proportion to the benefit deriving from restitution instead of compensation."43

The second form of retribution is compensation. Compensation is considered as reparation in narrow perspective, where compensation is related to financial matters or payment (money as the form of payment) to retribute the damages that have been occurred. Article 36 of the draft constitutes compensation as follows:

“1. The State responsible for an internationally wrongful act is under an obligation to compensate for the damage caused thereby, insofar as such damage is not made good by restitution.

2. The compensation shall cover any financially assessable damage including

\footnotetext{
${ }^{42}$ Richard K. Gardiner, International Law, Longman, 2003, p444.

${ }^{43}$ Note 40 , Art. 35.
}

loss of profits insofar as it is established." 44

Retribution and compensation usually come along together as one unit and have to be fulfilled by the violating country. 45

The last form of retribution is satisfaction, which includes non-material matter retribution. Concrete form of retribution is usually by apologizing to the violated country verbally. One thing to remember is satisfaction must be conformed appropriately and not embarass any party.

\section{The Instability of Conflict Countries}

\section{A. Conflict Country: Country in Armed Conflict}

There is not any definition given by the international law on conflict country. In terms of emphasizing a conflict country, this 'conflict' context has to be explained first. In this case, 'conflict' means 'armed conflict', which could be elaborated that a conflict country is a country having armed conflict and ongoing hostility in the country. There are some types of armed conflict stated in the humanitarian law. Distinguishing armed conflicts is essential because it will determine which law can be used to settle the dispute. ${ }^{46}$ Moreover, it provides information of what kind of armed conflicts happening in some countries and tries to look at different conflicts at

\footnotetext{
${ }^{44}$ Note 43, Art. 36.

${ }^{45}$ Ian Brownlie, Principles of Public International Law, Oxford University Press, 2012, p. 458.

${ }^{46}$ Daniel Lieberfeld, "Theories of Conflict and the Iraq War", International Journal of Peace Studies Vol. 10, No. 2, 2005 p6.
} 
different perspectives based on the type of the armed conflict.

The development of armed conflict has progressed rapidly since the establishment of the United Nations. Despite the importance of the concept itself, the armed conflict is not defined specifically by Geneva Conventions of 1949. A description of armed conflict was explained well in the International Criminal Tribunal for Former Yugoslavia as follows:

"On the basis of the foregoing, we find that an armed conflict exists whenever there is a resort to armed force between States or protracted armed violence between governmental authorities and organized armed groups or between such groups within a State. International humanitarian law applies from the initiation of such armed conflicts and extends beyond the cessation of hostilities until a general conclusion of peace is reached; or, in the case of internal conflicts, a peaceful settlement is achieved. Until that moment, international humanitarian law continues to apply in the whole territory of the warring States or, in the case of internal conflicts, the whole territory under the control of a party, whether or not actual combat takes place there., ${ }^{47}$

This definition given by ICTY has made a wide scope in terms of hostilities and combats. Furthermore, this indicates a multi-dimensional aspect between international armed conflict and noninternational armed conflict. This description clarifies that there are at least two kinds of armed conflict, although there are few other specific types of armed conflict that can be included.

${ }^{47}$ International Criminal Tribunal for former Yugoslavia, Prosecutor vs Dusco Tadic, Decision of the Defence Motion on Interlocutory Appeal on Jurisdiction, Appeals Chamber, 2 October 1995, p70.

\section{International Armed Conflict}

International armed conflict is one the classic types of armed conflict stated in Common Article 2 of Geneva Conventions, "all cases of declared war or any other armed conflict which may arise between two or more High Contracting Parties...". Hence, whenever two or more armed soldiers from two contracting states of Geneva Convention of 1949 involved in hostility, Geneva Convention and Additional Protocol I will apply. ${ }^{48}$

The intensity, severity, and duration of a hostility is not relevant to determine whether any form of attacks would be considered as an international armed conflict or not. Because theoretically, any border incidence and shooting from a military aircraft is considered sufficiently to justify the application of $\mathrm{Ge}$ neva Conventions and Additional Protocol I. This condition is entirely different from the non-international armed conflict, which intentity, severity and duration are considered as relevant to determine non-international armed conflict. ${ }^{49}$

\section{Non-International Armed Conflict} Non-international armed conflict occurs when there is an armed conflict between a government and rebel groups or militias in one country without any intervention by other countries or the United $\mathrm{Na}$ tions. ${ }^{50}$ The legal basis of this kind of

\footnotetext{
${ }^{48}$ Ray Murphy, "Contemporary Challenges to the Implementation of International Humanitarian Law", Connections: The Quarterly Journal Vol. 3, No.3, 2004, p101.

${ }^{49}$ R. Burchill, N. White dan J. Morris, eds., International Conflict and Security Law Essays in Memory of Hilaire McCoubrey, Cambridge University Press, 2005, p108.

${ }^{50}$ Note 49.
} 
armed conflict is Article 3 of 1949 Geneva Conventions considered as 'mini convention' for this armed conflict. The other legal basis is Additional Protocol 2 which includes more technical aspects.

\section{National Liberation War}

War of National liberation belongs to armed conflicts in which people struggle to exercise their right to selfdetermination. The classic example is people fight a colonial power in order to obtain their independence. ${ }^{51}$ As such, these armed conflicts were already present in the nineteenth and the beginning of the twentieth century when Latin American peoples fought for their independence against Spain and Portugal. However, what distinguishes modern wars of liberation is the application of the rules regulating an international armed conflict, whereas in the past these rules were only applicable in the case of recognition of belligerency. In all other situations only the rules of noninternational armed conflicts applied. Consequently, the early wars of national liberation in the twentieth century were only regulated by Common Article 3 of the Geneva Conventions. ${ }^{52}$ However, In 1974, one year after the adoption of resolution 3103 (XXVIII), the first session of the Diplomatic Conference on Humanitarian Law in Geneva voted in favour of Article 1 Paragraph 4 of Proto-

\footnotetext{
${ }^{51}$ Georges Abi-Saab, "War of National Liberation in the Geneva Conventions and Protocols", Collected Courses of the Hague Academy of International Law, Vol.165, 1979, p380.

${ }^{52}$ Dietrich Schindler, The Different Types of Armed Conflicts According to the Geneva Conventions and Protocols, Nijhoff, 2014, p163.
}

col I, declaring that wars of national liberation are on equal footing with international armed conflicts. ${ }^{53}$

\section{Internationalized Non Interna- tional Armed Conflict}

Internationalized non international armed conflict is an armed conflict in a country between government's armies and rebel groups intervened by one or more third countries that support either the government or the rebel groups. Geneva Convention or Additional protocol does not provide any solution regarding this issue as a part of humanitarian law. ${ }^{54}$

To examine or determine whether a conflict is internationalized or not, there are two main issues that have to be solved. First, how far the intervention has been conducted by the third country. Of course, not all forms of intervention can change the status of a noninternational conflict to international conflict. Second, to what extent the rules governing international armed conflicts are applicable to all the parties of the conflict? This issue is somehow not consented by any scholars or jurisprudence. However, it is probably better to argue that the complete conflict becomes internationalized and that the rules covering international armed conflicts apply to all the parties of the conflict, certainly when the intervening state provides for massive support. ${ }^{55}$

\section{Armed Conflict with the United Nations Involvement}

\footnotetext{
${ }^{53}$ E. David, Principlesof the Law of the War, Bruylant, 2002, p162.

${ }^{54}$ Note $39, \mathrm{pp} 400-401$.

${ }^{55}$ Note 39.
} 
The United Nations has become more active in the involvement of armed conflicst since the end of cold war. There are two distinctive situations, the United Nations authorizes the use of force by its member states against another member state and the United Nations has sent peacekeepers which guard the peace in a state with a non-internationalized armed conflict or between the two states. ${ }^{56}$

The first situation is not too problematic, while the UN does not do anything actively, but it gives authorisation of force use by member states to push another state to conform the UN's resolution. ${ }^{57}$ The second situation is more problematic than the first one. It really involves the United Nations as an international organization. However, in most cases the international humanitarian law will not be applicable between the United Nations peacekeepers and the parties of the armed conflict, since the mandate of the former generally does not provide for coercive action against one of the parties in the conflict unless in case of self-defence. This does not mean that the whole conflict becomes internationalized if the attacks against the United Nations peacekeepers are scarce. Only when attacks are recurrent and of certain gravity the whole internal conflict in total can become international-

\footnotetext{
${ }^{56}$ Jed Odermatt, "Between Law and Reality: 'New Wars' and the International/NonInternational Armed Conflict Dichotomy", Amsterdam Law Forum Vol. 5, 2013, p20.

${ }^{57}$ Gerry Simpson, "The War in Iraq and International Law", Melbourne Journal of International Law Vol. 6, No. 1 2005, p5.
}

ized, although it is not without controversy. $^{58}$

\section{B. Study Cases: Libya, Syria, Somalia, Iraq and Pakistan}

\section{Iraq}

Iraq is one the countries that conforms the criteria of a conflict country. This armed conflict was mainly affected by the United States' invasion to Iraq in 2003. This invasion was marked as the first invasion that United States had done since the cold war and the first one in the Middle-East. ${ }^{59}$ This armed conflict between Iraq and the United States led to many casualties. Iraq Family Health Survey surveyed that the death toll from March 2003 to June 2006 reached $150.000{ }^{60}$ The British Pollster Opinion Research Business estimated at least one million Iraqi civillian died between March 2003 and August 2007.

If determined by the subjects of this armed conflict, the armed conflict going on in Iraq was an International Armed Conflict between Iraq and the United States. Because of this situation, there were some cases of diplomats attacked by the terrorist or militias.

There was a bombing in the United Nations Compound on August 19th, 2003, killing at least 22 people. One of the deceased was a special ambassador of the United Nations, Sergio Vieira de Mello. In response, the United Nations responded by condemning the attacks

\footnotetext{
${ }^{58}$ C. Greenwood, "International Humanitarian Law and U.N. Military Operations", International Humanitarian Law Yearbook Vol. 1, 1998 pp25-26.

${ }^{59}$ Note 35, pp 1 .

${ }^{60}$ Iraq Body Count Press Release, 16 October 2006.
} 
and this had been an evaluation to practice of protection of diplomat, especially theUnited Nations Staff. After that, the United Nations Security Council adopted Resolution 1770 to intervene more in solving humanitarian and diplomatic problems in Iraq. ${ }^{61}$ Iraq was responsible for the attacks because Iraq as a government failed to conform its obligations to protect diplomats in its territory. There was no control of Iraqi officials and the slow response led to the bombing of the United Nations Compound. ${ }^{62}$ There were also bombings of Jordan and Turkish embassy proving the inability of Iraqi Government to protect the premises and diplomatic staff in its territory. If the sending state wished to activate dispute settlement regarding Iraq's responsibility, Iraq could certainly be ordered to compensate or restitute. In the mean time, Iraqi government addressed condolesence, condemned the attacks, and would pursue the attackers.

\section{Syria}

The armed conflict in Syria, starting in 2011, still continues now. A peaceful demonstration took place to show the dissatisfaction of the people on the Syiria's regime. The conflict was also affected by the domestic and religion issues among the community groups in Syria. ${ }^{63}$ Because of this unstable situa-

\footnotetext{
${ }^{61}$ United Nations Security Council, Resolution 1770 (2007), Para. 6.

${ }^{62}$ Joel Roberts, "What's Next After Zarqawi's Death?", http://www.cbsnews.com/news/whatsnext-after-zarqawis-death/, retrieved on 23 April 2017.

${ }^{63}$ Eline Vaessen, "The Syrian Civil War: A Historical Analysis of the Role of Syria's Interreligious Relations, Secterian Politics and Regional Positioning Leading up to the Civil
}

tion in Syria, a separatist group of terrorists named The Islamic State of Iraq and the Levant (ISIL) had developed in Syria and started a civil war in Syria. Other third countries such as the United States, Qatar, Turkey, and Saudi Arabia supported the rebel groups. ${ }^{64}$ Meanwhile, Iran, Russia and Iraq are the countries who supported Assad's regime. ${ }^{65}$ Over 250.000 civilians and soldiers were killed during 2011 until today. ${ }^{66}$

This armed conflict started as noninternational armed conflict. However, there were interventions done by the third countries, soldiers and air strike of the United States and Russia were deployed in Syria. The level of intervention by the third parties in Syria's armed conflict made this conflict internationalized non-international armed conflict.

In this situation, security of the diplomats in Syria got vulnerable. There were some attacks on diplomats and premises when this armed conflict occurred. One particular case was the attacks on the embassy of the USA and France. Both ambassadors, Robert S. Ford and Eric Chevallier joined one of the demonstrations against the Assad's regime. In response, groups of Assad's supporters attacked both em-

War", Thesis Erasmus School of History, Culture and Communication, Rotterdam, 2014, p60.

64،'Syria's Civil War Explained from the Beginning",

http://www.aljazeera.com/news/2016/05/syriacivil-war-explained-160505084119966.html, retrieved on 19 April 2017.

${ }^{65}$ Nader Hashemi dan Danny Postel, ed., The Syria Dilemma, MIT Press, 2013, p4.

66"Syria: The Story of the Conflict", http://www.bbc.com/news/world-middle-east26116868, retrieved on 19 April 2017. 
bassies. ${ }^{67}$ The embassy called for help and reinforcement to Syria's official, but the reinforcement was too slow that both embassy premises suffered from the attack and got damaged. Both embassies condemned Syrian government because of the 'denial' shown by Syrian officials to protect the embassies. Because of the attacks, both the United States and France could demand responsibility by prosecuting Syria through arbitrary institution and International Court of Justice.

\section{Somalia}

From 2009 until now, Somalia has undergone a civil war in its territory. This armed conflict started in February 2009, when the conflict too place among the federal government of Somalia, the African Union, and Islamic militias such as al-shaabab, Sufis ASWJ and others. ${ }^{68}$ With the help of Peacekeeper and Kenyan Soldiers supporting the government's side, this armed conflict could be an internationalized armed conflict. But because the intervention was conducted to help the government, it could still be considered as a non-international conflict. Otherwise, with the involvement of the UN Peacekeeper soldiers, this conflict certainly became an armed conflict with the UN involvement.

This unstable situation in Somalia led to numerous attacks on diplomats.

\footnotetext{
${ }^{67}$ "Crowds Attack US, French Embassies in Damascus", http://www.voanews.com/a/syrianarmored-vehicles-storm-central-city-125340208/142085.html, retrieved on 23 April 2017.

68"'E. African Nations Back Kenyan Offensive in Somalia”, http://www.voanews.com/a/eastafrican-nations-back-kenyan-offensive-insomalia-132374053/147039.html, retrieved on 19 April 2017
}

One of them was bombing on Chinese Embassy in Mogadishu killing 15 people, including a Chinese diplomatic staff. In response, the Chinese Foreign Ministry evacuated the diplomatic staffs to a safe place and condemned the attack. ${ }^{69}$ Somali government also condemned the attack and ensured the premises would be fixed by the Somalia government. ${ }^{70}$ This action which was done by the Somali government was actually one of the forms of state responsibility. They also apologized to Chinese government, which fulfilled the satisfaction. But ifthe Chinese Government decided to demand more forms of responsibility from the Somali Government, the Chinese Government could prosecute Somali Government by using arbitrary institution and International Court of Justice.

\section{Libya}

Libyan Crisis started in 2011 where Muammar Gaddafi Loyalist and rebel groups fought each other to retain the undisputed power of Libya. Rebel factions named National Transitional Council fought the Libyan Arab Jamahiriya which was Muammar Gaddafi's loyalist. NATO intervened by helping rebel groups and in the end, Muammar Gaddafi's regime was defeated and Muammar Gaddafi was killed on October 20th, 2011. ${ }^{71}$ However, the civil war

\footnotetext{
69"Deadly Terrorist Attack in Somalia Hits Chinese Embassy", http://thediplomat.com/2015/07/deadly-terroristattack-in-somalia-hits-chinese-embassy/, retrieved on 30 Maret 2017.

${ }^{70}$ Note 69.

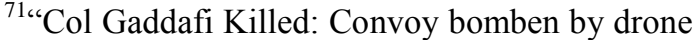
Flown by Pilot in Las Vegas", http://www.telegraph.co.uk/news/worldnews/afri caandindianocean/libya/8839964/Col-Gaddafi-
} 
did not find its way to end. The second civil war occurred between the newly formed government and Islamist named General National Congress. Moreover ISIL and Shura Council of Benghazil Revolutionaries took part as subject to this civil war. This civil war still occurs till now. ${ }^{72}$

This unstable situation resulted in some attacks on diplomats in Libya. One of them was the attacks on the United States Compound in Benghazi. This attack caused serious damages and loss, including the death of four United States diplomatic staffs and Chris Stephens, the Ambassador of the United States to Libya.

In response, Prime Minister of Libya Mustafa Abushagur condemned the attack and apologized to the United States. ${ }^{73}$ Besides, the representation of Libya in the United Nations, $\mathrm{Mr}$. Dabbashi made this statement regarding the Benghazi incident:

"The Government and the National General Congress have condemned that attach, which was carried out by an extremist group acting outside the law. In that regard, I shoul like to reiterate the condemnation of Libya's authorities. I also wish to reaffirm the intention of the Libyan Government to pursue the perpetrators and bring them to justice. The attack is no way serves the interests of Libya's people or authorities, It also cannot be consideren to have been in defence of Is-

killed-convoy-bombed-by-drone-flown-by-pilotin-Las-Vegas.html, retrieved on 19 April 2017.

${ }^{72}$ Chris Stephen, "War in Libya", https://www.theguardian.com/world/2014/aug/29 /-sp-briefing-war-in-libya, retrieved on 19 Aoril 2017.

${ }^{73 ،}$ "US Ambassador, Consul among 4 Killed in Militia Attack on Benghazi Consulate", https://www.rt.com/news/us-ambassador-libyakilled-946/, retrieved on 23 April 2017. lam; it does great damage to the image of Islam. Libya is party to the Vienna Convention on Diplomatic Relations. We assume our full responsibillity in connection with the protection of their staff and that of all non-Libya nationals on Libyan Territorry. Libya authorities will not allow any of these outlaws to jeopardize the stability of the country.",74

Libya was fully responsible for the incident based on the Vienna Convention on Diplomatic relations. It could be processed in the arbitrary institution and International Court of Justice. The statement by the Libyan conformed the satisfaction as a retribution of the state responsibility.

\section{Pakistan}

An armed conflict in Pakistan started in 2004 when Pakistani soldiers involved in a combat with al-Qaeda and Taliban This combat led to many hostilities and resulted in an armed conflict. This armed conflict, still going on now, caused the death of 61.500 people from January 2003 to December $2016 .^{75}$ This noninternational conflict led to the unstable situation in Pakistan and it affects the security in the territory of Pakistan, especially the security of diplomats.

There were some attacks on the diplomats in Pakistan, including bombing of the United States Consulate causing the death of one of USA diplomatic staff, David Foy. In response, Pakistani Government apologized to United States Government and condemned the attack.

\footnotetext{
${ }^{74}$ Secretary General of United Nations, Report of the Secretary General on the United States Support Mission in Libya (S/2012/675).

75"'Fatalities in Terrorist Violence in Pakistan", http://www.satp.org/satporgtp/countries/pakistan/ database/casualties.htm, retrieved on 19 April 2017.
} 
Pakistani government ensured the responsible party would be brought to justice. This response concluded that Pakistani Government fulfilled the satisfaction retribution. However, Pakistan was still fully responsible for the incident based on the Vienna Convention on Diplomatic relations and it could be processed in the arbitrary institution and International Court of Justice.

\section{Inability to Protect Diplomats by Af- ghanistan and Its Consequences}

\section{A. Afghanistan: A Conflict Country}

As a country, Afghanistan is an example of long-raging conflict country. The armed conflict has occurred in Afghanistan since 1979 until now. ${ }^{76}$ It started in 1978 when the Marxist ideology ruled the governement of Pakistan. This resulted in hostility between the government and the rebel groups. In the end, it started the first civil war in Afghanistan in a short time. ${ }^{77}$ Those rebel group was named Mujahideen that became insurgent against the sovereign government. This armed conflict attracted the third countries to somehow involve in this armed conflict. Uni Soviet sent their military advisor and soldires to back up the sovereign government, meanwhile Pakistan, the United States, and Saudi Arabia actively sent aids to the rebel groups. ${ }^{78}$ After the dissolve of the Soviet

\footnotetext{
${ }^{76}$ Michael Barry, A History of Modern Afghanistan, Cambridge University Press, 2006, p1.

${ }^{77}$ M. Nazif Shahrani dan Robert L. Canfield, Revolutions and Rebeliions in Afghanistan: Anthropological Perspectives,University of California Press, 1984, p2.

${ }^{78}$ Rizwan Hussain, Pakistan and the Emergence of Islamic Militancy in Afghanistan, Ashgate Publishing, 2005, pp 108-109.
}

Union, this first civil war quickly ended in 1992 when the Soviet Union did not send their soldiers anymore. ${ }^{79}$ The involvement of the third parties in this armed conflict made this conflict as internationalized non-international armed conflict, regarding the contribution of the Soviet Union, the USA, Pakistan, and Saudi Arabia.

But the armed conflict seemed not to go anywehere from Afghanistan. In 1994, a rebel and terrorist islamist group formed and made quick impact by taking over some of the Afghanistan territory. In 1998, most of the territory in Afghanistan was seized by the Taliban. ${ }^{80}$ However, Northern Alliance as the opposition kept continuing to fight Taliban, especially in the northen and eastern parts of Afghanistan.

On September 11th, 2001, the September 9 attacks commenced and the USA accused Taliban as the responsible party. The USA demanded to hand over Osama bin Laden but Afghanistan refused it. ${ }^{81}$ Hence, the USA invaded Afghanistan. This invasion caused the defeat of Taliban and in December 2001 Taliban had no longer power as the sovereign government. A new government under the leadership of Hamid Karzai was formed and International Security Assistance Force (ISAF) was established in accordance with the resolution of United Nations Security Council to help

\footnotetext{
${ }^{79}$ O.L. Sarin dan Lev Dvoretsk, The Afghan Syndrome: The Soviet Unions' Vietnam, Presidio, 1993, p2.

${ }^{80}$ Gilles Dorronsoro, The Taliban's Winnning Strategy in Afghanistan, Carnegie Endowment for International Peace, 2009, p7.

${ }^{81}$ Gilles Dorronsoro, Revolution Unending: Afghanistan, 1979 to the Present, Columbia University Press, 2005, p47.
} 
the government in the security and stabilization aspects. ${ }^{82}$ Basically, from 2001 to 2017, the armed conflict taking place in Afghanistan was International Armed Conflict. From the moment of the invasion of the USA to Afghanistan, it shows the international armed conflict. But after the defeat of Taliban and the rebeginning of Taliban insurgency until now, it becomes an Internationalized non-international armed conflict, considering the involvement of ISAF and the USA soldiers and drones in the armed conflict.

After losing legitimate power, Taliban continued to be an insurgent until now and committed many attacks on innocent people. Diplomats are also one of the Taliban's targets to attack. As mentioned before, statistically, Afghanistan is the country with the highest number of attacks on diplomats in decade. ${ }^{83}$ Some study cases will be described together with the responses of the related parties.

\section{B. Attack on Diplomats Cases}

The first case of the killing of five Uni Emirat Arab Diplomats in a bombing in southern Afghanistan marked the deadliest attack ever for the young nation's diplomatic corps, although it is too soon to tell who was behind it or if the Gulf envoys were even the targets. On January 11, 2017, the bomb targeted a guesthouse of Kandahar Government. Homayun Azizi, was wounded in the

\footnotetext{
${ }^{82}$ Theo Farrel dan Olivier Schmitt, The Causes, Character and Conduct of Armed Conflict, and the Effects on Civilian Populations, 19902010,Division of International Protection United Nations High Commissioner for Refugees (UNHCR), 2012, p14.

${ }^{83}$ Note 15 .
}

assault along with UAE Ambassador Juma Mohammed Abdullah al-Kaabi. The attack killed 11 people and wounded 18, said Gen. Abdul Razeq, Kandahar's police chief, who was praying nearby at the time of the blast. Razeq said that the investigators believed someone hid the bomb inside a sofa at the guesthouse. He said an ongoing construction project there might have allowed militants to plant the bomb. ${ }^{84}$

Dubai's ruler Sheikh Mohammed bin Rashid Al Maktoum, the UAE's prime minister and vice president, said on twitter that "there is no human, moral or religious justification for the bombing and killing of the people trying to help" others. On the Afghan side, authorities said the dead included two politicians, a deputy governor from Kandahar and an Afghan diplomat stationed at the embassy in Washington. The diplomats were expected to open a number of UAE-backed projects as part of an aid programme to Afghanistan. In honour of the dead, the government institutions across the UAE were directed to have a half-mast flag for three days. The Taliban denied carrying out the bombing, saying the attack was a result of "internal local rivalry". 85

\footnotetext{
${ }^{84}$ Jon Gambrell dan Mirwais Khan, "UAE Mourns 5 Diplomats Killed in Mysterious Afghan Bombing”, https://www.bloomberg.com/news/articles/201701-11/taliban-say-they-didn-t-plant-bombwounding-uae-diplomats, retrieved on 9 Mei 2017.

85،"Five UAE Diplomats Killed in Afghanistan Attack", http://www.aljazeera.com/news/2017/01/uaeambassador-afghanistan-wounded-kandaharblast-170110172931399.html, retrieved on 9 Mei 2017.
} 
The second case was the attack of the German Consulate in northern Afghanistan on November 11, 2016. It was attacked when a suicide car bomber rammed the compound, killing six people and wounding more than 120 people, said Afghan police and the German foreign minister. Four of the dead, two civilians and two unidentified bodies, were brought to the Balkh hospital, said Dr. Noor Mohammad Faiz. He said 128 people were wounded in the attack.Germany's Foreign Minister Frank-Walter Steinmeier said six people had been confirmed dead. He added in a statement that "all German and Afghan employees of the consulate remained unharmed."The car exploded at the gate of the consulate in the city of Mazar-iSharif, destroying the gate and wall around 11.10 p.m. Thursday, said Abdul Raziq Qaderi, head of the security for Balkh province. The blast destroyed the Mazar Hotel, where the consulate was based, and surrounding buildings. Residents said that casualties were inside the building at that late hour, though an ensuing gun battle raged for around five hours. ${ }^{86}$ The attack was carried out "by heavily armed terrorists," he said, and added, "The attackers were fought off by the consulate's security personnel, Afghan security forces, and German, Georgian, Belgian and Latvian special forces stationed in the city as part of the Resolute Support mission."

\footnotetext{
${ }^{86}$ Antonio Giustozzi dan Christopher Reuter, "The Insurgents of the Afghan North: The Rise of the Taleban, the Self-abandonment of the Afghan Government and the Effects of ISAF's 'Capture-and-kill Campaign'", Afghanistan Analysts Network Thematic Report Vol. 4, 2011, p59.
}

President Ashraf Ghani called the the attack a "crime against humanity and all international laws." The United Nations' assistance mission in Afghanistan also condemned it. In a statement there were 19 women and 38 children getting injured. "Most of the injured suffered minor wounds from broken glass while those with serious injuries remained hospitalized." More than 100 houses and shops were damaged, it said.The Taliban claimed responsibility for the attack. ${ }^{87}$

The third case was the attack of the Spain Embassy in December 2015, The Taliban claimed responsibility for a car bomb attack on a guest house near the Spanish embassy in Kabul on Friday, and said fighting was still going on at the scene. Gunfire was reported immediately following the explosion in a heavily protected area of the capital close to many foreign embassies and government buildings. ${ }^{88}$ Officials said the police were on the scene. At least three insurgents appeared to be involved in the attack, a police official said. A Taliban spokesman said the attack targeted "an invader's guest house," according to Reuters. According to The Wall Street Journal, the assault on the Spanish facility was conducted by gunmen and suicide bombers. The bomb blast was so big that shake the buildings across the

\footnotetext{
${ }^{87}$ Hamid Fahim, "Six Dead, Dozens Wounded as Afghan Taliban Strike German Consulate", https://www.yahoo.com/news/taliban-attackgerman-consulate-afghanistans-mazar-sharif201341427.html retrieved on 10 Mei 2017.

${ }^{88}$ Bilal Sarwary, "Spanish Embassy Attack in Kabul: Special Forces at Scene", http://www.bbc.com/news/av/world-asia35075184/special-forces-at-kabul-attack-scene, retrieved on 10 Mei 2017.
} 
diplomatic district in the city center. The Journal was able to contact a Spanish official who confirmed an "ongoing" security situation. ${ }^{89}$

The last case was the attack on the United States Consulate on September 13, 2013. Eyewitnesses said the explosion rocked the walls nearby buildings. The security forces returned fire on the attackers in a gunfight that left at least two police and the attackers were dead, and more than a dozen got wounded. The U.S. State Department said there were no American casualties. Mohammad Sharif, a security guard for a private Afghan security company, was wounded in the attack. Speaking from the hospital in Herat, he said there were two blasts. The State Department spokeswoman, Marie Harf said at dawn a truck carrying a number of attackers drove to the front gate of the compound while firing on Afghan forces protecting the area. Then, the entire truck exploded, damaging the gate area. Harf said those in the consulate took shelter in the building as security forces fought to repel the attack. The US security staff, she said, "addressed" attackers who managed to enter the compound. Some attackers appeared to be wearing suicide explosives. $^{90}$

\footnotetext{
89،"Spain's Embassy in Afghanistan is Under Attack", http://www.businessinsider.co.id/reportspains-embassy-in-afghanistan-is-under-attack2015-

12/?r=US\&IR=T\#5rGbz7MF17Gmwxks.97, accessed on 11 Mei 2017.

${ }^{90}$ Sharon Behn, "Taliban Militants Attack US Consulate in Afghanistan", http://www.voanews.com/a/afghan-militantsstrike-us-consulate/1748890.html, retrieved on 11 Mei 2017.
}

The International Security Assistance Force confirmed via twitter that "enemy forces" had conducted an unsuccessful attack on the U.S. consulate. It said the international and Afghan forces secured the facility and all the militants were killed. The U.N. Security Council condemned the militant attack on the U.S. consulate in the western Afghan town of Herat that killed three Afghan guards and one interpreter. Nearly 20 people were wounded in the assault. The Security Council said late Friday in a statement "terrorism in all of its forms and manifestations is criminal and unjustifiable." Officials stated that the Taliban got engaged in a gunfight and a suicide bombing just outside the consulate building early Friday. The international security forces returned fire and authorities told that all the militants, some wearing suicide vests, were killed. The Security Council said no terrorist act could reverse "the path towards Afghanled peace, democracy and stability in Afghanistan." ${ }^{11}$

\section{Analysis on Protection of Diplomats} Afghanistan did not ratify all five diplomatic conventions, while it only ratified and adopted two conventions, namely Vienna Convention on Diplomatic Relations of 1961 and Convention on the Prevention and Punishment of Crimes against Internationally Protected Persons including Diplomatic Agents of 1973. All four of sending states also ratified those conventions. Thus, these conven-

\footnotetext{
${ }^{91}$ United States Department of State Bureau of Diplomatic Security, Bureau of Diplomatic Security: Year in Review 2013, United States Department of State Bureau of Diplomatic Security, 2014, p2.
} 
tions would be the legal basis on the analysis of protection of diplomats in Afghanistan.

The attack on UEA Diplomats killing the diplomats fulfilled the Article 29 of Vienna Convention Diplomatic Relations. $^{92}$ Afghan officials failed to protect the five diplomats who were killed in the attack, meaning they did not do their obligation well. Meanwhile, the other three attacks targeted the premises of the sending state. This indicates that the condition in Article 22 was fulfilled by the failure of Afghan officials to protect the premises. ${ }^{93}$ It is obvious that based on the cases, the Afghan officials already tried their best to protect both the diplomats and the premises. Yet, it is debatable whether or not Afghanistan has some kind of defense. But based on this convention, certainly Afghan officials violated Vienna Convention on Diplomatic Relations.

The second convention is Convention on the Prevention and Punishment against Protected Persons, including Diplomatic Agent of 1973. The attack on UEA Diplomats Case with the death of five diplomats and the injury sustained by UEA Ambassdor showed that Afghanistan violated Article 2 Paragraph (3) of the Convention on the Prevention and Punishment against Protected Persons, including Diplomatic Agent of 1973. The phrase “....law to take all appropriate measures to prevent other attacks on the person, freedom or dignity..." failed to be conformed by the Afghan Officials due to the death of five

${ }^{92}$ Note 13 , Art. 29.
${ }^{93}$ Note 13 . Art. 22. diplomats. ${ }^{94}$ Moreover, with the attack on premises in the other cases, it also proved that Afghanistan violated Article 2 Paragraph (1), Letter $b$, focusing on protecting premises of the sending state. $^{95}$

\section{Analysis on State Responsibility}

As discussed earlier, Vienna Convention on Diplomatic Relations of 1961 and Convention on the Prevention and Punishment of Crimes against Internationally Protected Persons, including Diplomatic Agent of 1973 are two of diplomatic conventions that can be used as a legal basis of the prosecution. However, Afghanistan was not a party of the Optional Protocol concerning the Compulsory Settlement of Disputes Vienna Convention on Diplomatic Relations of 1961, thus the mechanism included in the optional protocol cannot be used as a legal basis. On the other hand, all of the related parties already become the Convention on the Prevention and Punishment of Crimes against Internationally Protected Persons, including Diplomatic Agent of 1973 contracting states. So, this convention can be used as the legal basis of the state responsibility.

Article 13 of the convention states: "1. Any dispute between two or more States Parties concerning the interpretation or application of this Convention which is not settled by negotiation shall, at the request of one of them, be submitted to arbitration. If within six months from the date of the request for arbitration the parties are unable to agree on the organization of the arbitration, any one of those parties may refer the dispute to the International Court of Justice by request

\footnotetext{
${ }^{94}$ Note 32. Art. 2 Par. (3).

${ }^{95}$ Note 32 Art. 2 Par. (1) Let b.
} 
in conformity with the Statute of the Court."

"2. Each State Party may at the time of signature or ratification of this Convention or accession thereto declare that it does not consider itself bound by paragraph 1 of this article. The other States Parties shall not be bound by paragraph 1 of this article with respect to any State Party which has made such a reservation." "3. Any State Party which has made a reservation in accordance with paragraph 2 of this article may at any time withdraw that reservation by notification to the Secretary-General of the United Nations." 96

As explained earlier, Afghanistan proved to be responsible for the attacks in its territory based on both Vienna Convention on Diplomatic Relations of 1961 and Convention on the Prevention and Punishment of Crimes against Internationally Protected Persons, including Diplomatic Agent of 1973. Since Afghan officials violated Article 2 Paragraph (3) and Article 2 Paragraph (1) Letter B, the mechanism in Article 13 could be done by the sending state. It is obvious that Afghanistan was responsible for the attacks and loss suffered by the sending state.

\section{CONCLUSION}

The inviolability of diplomatic staff is the key rules in Vienna Convention on the Diplomatic Relations and other diplomatic conventions. ${ }^{97}$ This also means that receiving state has responsibility to protect diplomatic staff in their country with "all appropriate steps". Thus, the failure to conform such responsibility is a violation of international law and the convention. However, the number of the

\footnotetext{
${ }^{96}$ Note 32 , Art. 13

${ }^{97}$ Note 13 .
}

attacks on diplomatic staff gets increased statistically across the world. The Landmark case of the attacks on the diplomatic staff was Iran Hostage Crisis, where 52 United States diplomatic staff became hostages for 444 days in Iran. ${ }^{98}$ In addition, the attacks on diplomatic staff got worsen in 1980, where 400 terrorist attacks targeted diplomatic and consular staff in more than 60 countries. Diplomatic staff posted in conflict countries became more vulnerable to attacks of the terrorist groups. Thus, one of the most renowned conflict countries is Afghanistan, where civil war and international armed conflict have been occurring in this country until this day. Statistically, Afghanistan had the highest number of attacks on diplomatic staff from 200-2017. This indicated that the country faced a problem as a sovereign country. It could not meet the needs and protection of diplomats and made the situation get worse domestically and globally. The sending state could not trust the ability of Afghan officials to do their obligations. Moreover, the armed conflict in Afghanistan is still going on and the attacks on diplomats in the future seem inevitable. Hence, Afghanistan is an interesting country to be discussed further, based on the geo-political and legal perspectives. This inablity shown by the Afghanistan shows that it has a problem in wider perspectives.

Conflict countries have their own domestic problems related to the humanitarian and human rights issue. But, those are not the only two issues that they have face. Afghanistan faces dip-

\footnotetext{
${ }^{98}$ Note 14.
} 
lomatic issues regarding the attacks on diplomats in the country. There might be a finding related to this issue, especially the ones existing in Afghanistan and conflict countries on diplomatic and humanitarian problems. Afghanistan is fully responsible for the attacks on diplomats in its territory and Afghan officials fail to protect the diplomats and the premises based on the study cases given. It is better that the Afghanistan and the conflict countries evaluate their diplomatic manuals submitted to the sending states which posted their staff in Afghanistan. The diplomatic manual has to emphasize the technical matters related to the security of the diplomats and the premises. Practically, the use of military convoy wherever the diplomats go, the assignation of military and police surrounding the premises, and the application of curfew will minimize the chance of the attacks on diplomats. Moreover, the United Nations' role in this matter is expected to help solve these diplomatic and humanitarian problems as a whole.

\section{REFERENCES}

\section{Books}

Arthur Nussabaum, A Conchise History of the Law of Nations, s.n, Bandung, 1969.

Boer Mauna, Hukum Internasional: Pengertian, Peranan, dan Fungsi dalam Era Dinamika Global, Penerbit Alumni, Bandung, 2000.

Coleman Phillipson, The International Law and Customs of Ancient Greece and Rome, Macmillan and Co., London, 1911.
David J. Bederman, International Law in Antiquity, Cambridge University Press, Cambridge, 2001.

Dietrich Schindler, The Different Types of Armed Conflicts According to the Geneva Conventions and Protocols, Nijhoff, Leiden, 2014.

E. David, Principlesof the Law of the War, Bruylant, Brussels, 2002.

Eileen Denza, Diplomatic Law: Commentary on The Vienna Convention on Diplomatic Relations, Oxford University Press, Oxford, 1998.

Gilles Dorronsoro, Revolution Unending: Afghanistan, 1979 to the Present, Columbia University Press, New York, 2005.

Gilles Dorronsoro, The Taliban's Winnning Strategy in Afghanistan, Carnegie Endowment for International Peace, Wasington DC, Moscow, Beijing, Beirut dan Brussels, 2009.

Harold Nicolson, Diplomacy, Institute for the Study of Diplomacy, Washington, 1988.

Ian Brownlie, Principles of Public International Law, Oxford University Press, Oxford, 2012

J. Alan, Hostages and Hostage Takers in the Roman Empire, Cambridge University Press, Cambridge, 2006.

M. Nazif Shahrani dan Robert L. Canfield, Revolutions and Rebeliions in Afghanistan: Anthropological Perspectives,University of California Press, Berkeley, 1984.

Michael Barry, A History of Modern Afghanistan, Cambridge University Press, Cambridge, 2006.

Nader Hashemi dan Danny Postel, ed., The Syria Dilemma, MIT Press, Boston, 2013. 
O.L. Sarin dan Lev Dvoretsk, The Afghan Syndrome: The Soviet Unions' Vietnam, Presidio, Kalifornia, 1993.

R. Burchill, N. White dan J. Morris, eds.,International Conflict and Security Law Essays in Memory of Hilaire McCoubrey, Cambridge University Press, Cambridge, 2005.

Richard K. Gardiner, International Law, Longman, London, 2003.

Rizwan Hussain, Pakistan and the Emergence of Islamic Militancy in Afghanistan, Ashgate Publishing, Farnham, 2005.

Sumaryo Suryokusumo, Hukum Diplomatik Teori dan Kasus, Alumni, Bandung, 2005.

Syahmin AK, Hukum Perjanjian Internasional: Menurut Konvensi Wina 1969, CV. Armico, Bandung, 1985.

Theo Farrel dan Olivier Schmitt, The Causes, Character and Conduct of Armed Conflict, and the Effects on Civilian Populations, 1990-2010,Division of International Protection United Nations High Commissioner for Refugees (UNHCR), Jenewa, 2012.

United States Department of State Bureau of Diplomatic Security, Bureau of Diplomatic Security: Year in Review 2013, United States Department of State Bureau of Diplomatic Security, Washington, 2014.

\section{Journals}

Antonio Giustozzi dan Christopher Reuter, "The Insurgents of the Afghan North: The Rise of the Taleban, the Selfabandonment of the Afghan Government and the Effects of ISAF's 'Capture-andkill Campaign", Afghanistan Analysts Network Thematic Report Vol. 4, 2011.

C. Greenwood, "International Humanitarian Law and U.N. Military Opera- tions", International Humanitarian Law Yearbook Vol. 1, 1998.

Christos L. Rozakis, "Terrorism and the Internationally Protected Persons in the Light of the ILC's Draft Articles", The International and Comparative Law Quarterly Vol. 23, Iss. 1, 1974.

Daniel Lieberfeld, "Theories of Conflict and the Iraq War", International Journal of Peace Studies Vol. 10, No. 2, 2005.

Eileen Young, "The Development of The Law of Diplomatic Relations", British Yearbook of International Law Vol. 40, No.1, 1964.

Georges Abi-Saab, "War of National Liberation in the Geneva Conventions and Protocols", Collected Courses of the Hague Academy of International Law, Vol.165, 1979.

Gennady M. Danilenko, “The Relevance of Humanitarian and Diplomatic Law to the Conflict in the Gulf", Duke Journal of Comparative and International Law, Vol. 125, 1991.

Gerry Simpson, "The War in Iraq and International Law", Melbourne Journal of International Law Vol. 6, No. 12005.

Jed Odermatt, "Between Law and Reality: 'New Wars' and the International/Non-International Armed Conflict Dichotomy", Amsterdam Law Forum Vol. 5, 2013.

Joseph S. Nye, "The Changing Nature of World Power", Political Science Quarterly, Vol. 105, No. 2, 1990.

L.S. Farhangi, "Insuring against Abuse of Diplomatic Immunity", Stanford Law Review Vol. 38, No. 6, 1985-1986.

M.L. Benedek, "The Diplomatic Relations Act: The United States Protects Its Own", Brooklyn Journal of International Law Vol. 5, 1979. 
Michael Wood, "The Immunity of Official Visitors", Max Planck Yearbook of United Nations Law Vol. 16, 2012.

Montell Ogdon, "The growth of the Purpose In The Law of Diplomatic Immunnity", The American Journal of International Law Vol. 31, No.3, 1937.

Ray Murphy, "Contemporary Challenges to the Implementation of International Humanitarian Law", Connections: The Quarterly Journal Vol. 3, No.3, 2004.

Rene Vark, "Personal Inviolability and Diplomatic Immunity in Respect of Serious Crime", Juridica International Vol. 8, 2003.

Yu Long Ling, "A Comparative Study of the Privileges and Immunity of United Nations Member Representatives and Officials with the Traditional Privileges and Immunities of Diplomatic Agents", Washington and Lee Law Review, Vol. 33, Iss. 1, 1976.

\section{Thesis}

Eline Vaessen, "The Syrian Civil War: A Historical Analysis of the Role of Syria's Interreligious Relations, Secterian Politics and Regional Positioning Leading up to the Civil War", Thesis Erasmus School of History, Culture and Communication, Rotterdam, 2014.

Esther M.F. Warouw, “Tanggung Jawab Negara Melindungi Diplomat dan Gedung Perwakilan Asing (Studi Kasus: Kematian Duta Besar dan Pengrusakan Gedung Perwakilan Amerika Serikat di Benghazi Libya)", Thesis Bachelor of Law Universitas Indonesia, Depok, 2013.

Tyler Q. Houlton, "The Impact of the 1979 Hostage Crisis in Iran on the U.S. Presidential Election of 1980", Thesis of Master of Arts in Liberal Studies Georgetown University, Washingtown D.C., 2011.

\section{Legal Documents}

Convention on Special Mission 1969, opened for signature on 8 December 1960, (entered into force 21 June 1985).

Convention on the Prevention and Punishment of Crimes against Internationally Protected Persons, including Diplomatic Agents 1973, opened for signature 14 December 1973, (entered into force 20 February 1977).

ILC Draft Articles on State Responsibility for Internationally Wrongful Acts(2001), adopted by International Law Commission on 12 December 2001.

International Court of Justice, Case concerning United States Diplomatic and Consular Staff in Tehran (United States v. Iran), 24 Mei 1980.

International Criminal Tribunal for former Yugoslavia, Prosecutor vs Dusco Tadic, Decision of the Defence Motion on Interlocutory Appeal on Jurisdiction, Appeals Chamber, 2 October 1995.

United Nations Security Council, Resolution 1770 (2007).

Vienna Convention on Consular Relations 1963, opened for signature 24 April 1963, (entered into force 19 March 1967).

Vienna Convention on Diplomatic Relations 1961, opened for signature 18 April 1961, (entered into force 24 April 1964).

Vienna Convention on the Representation of States in Their Relations with International Organisations of a Universal Character 1975, opened for signature 13 March 1975, (not yet entered into force). 


\section{Other Documents}

Secretary General of United Nations, Report of the Secretary General on the United States Support Mission in Libya (S/2012/675).

\section{Internets}

"Col Gaddafi Killed: Convoy bomben by drone Flown by Pilot in Las Vegas", http://www.telegraph.co.uk/news/worldn ews/africaandindianocean/libya/8839964 /Col-Gaddafi-killed-convoy-bombed-bydrone-flown-by-pilot-in-Las-Vegas.html, accessed on 19 April 2017.

"Crowds Attack US, French Embassies in

http://www.voanews.com/a/syrianarmored-vehicles-storm-central-city-125340208/142085.html, accessed on 23 April 2017.

"Deadly Terrorist Attack in Somalia Hits Chinese Embassy", http://thediplomat.com/2015/07/deadlyterrorist-attack-in-somalia-hits-chineseembassy/, accessed on 30 Maret 2017.

"E. African Nations Back Kenyan Offensive in Somalia", http://www.voanews.com/a/east-africannations-back-kenyan-offensive-insomalia-132374053/147039.html, accessed on 19 April 2017.

"Fatalities in Terrorist Violence in Pakistan", http://www.satp.org/satporgtp/countries/ pakistan/database/casualties.htm, accessed on 19 April 2017.

"Five UAE Diplomats Killed in Afghanistan Attack", http://www.aljazeera.com/news/2017/01/ uae-ambassador-afghanistan-wounded- kandahar-blast-170110172931399.html, accesed on 31 Januari 2017.

"Spain's Embassy in Afghanistan is Under Attack", http://www.businessinsider.co.id/reportspains-embassy-in-afghanistan-is-underattack-2015-

12/?r=US\&IR=T\#5rGbz7MFl7Gmwxks 97, accessed on 11 Mei 2017.

"Syria: The Story of the Conflict", http://www.bbc.com/news/worldmiddle-east-26116868, accessed on 19 April 2017.

"Syria's Civil War Explained from the Beginning",

http://www.aljazeera.com/news/2016/05/ syria-civil-war-explained-

160505084119966.html, accessed on 19 April 2017.

"US Ambassador, Consul among 4 Killed in Militia Attack on Benghazi Consulate", https://www.rt.com/news/usambassador-libya-killed-946/, accessed on 23 April 2017.

Bilal Sarwary, "Spanish Embassy Attack in Kabul: Special Forces at Scene", http://www.bbc.com/news/av/worldasia-35075184/special-forces-at-kabulattack-scene, accessed on10 Mei 2017.

Chris Stephen, "War in Libya", https://www.theguardian.com/world/201 4/aug/29/-sp-briefing-war-in-libya, accessed on 19 April 2017.

Hamid Fahim, "Six Dead, Dozens Wounded as Afghan Taliban Strike German Consulate", https://www.yahoo.com/news/talibanattack-german-consulate-afghanistansmazar-sharif-201341427.html, accessed on 10 Mei 2017.

Joel Roberts, "What's Next After Zarqawi's Death?", http://www.cbsnews.com/news/whats- 
next-after-zarqawis-death/, accessed on 23 April 2017.

Jon Gambrell dan Mirwais Khan, "UAE Mourns 5 Diplomats Killed in Mysterious Afghan Bombing", https://www.bloomberg.com/news/articl es/2017-01-11/taliban-say-they-didn-tplant-bomb-wounding-uae-diplomats, accessed on 9 Mei 2017.

Sharon Behn, "Taliban Militants Attack US Consulate in Afghanistan", http://www.voanews.com/a/afghanmilitants-strike-usconsulate/1748890.html, accessed on 11 Mei 2017. 